\title{
Uji Aktivitas Antiinflamasi Infusa Daun Afrika (Vernonia amygdalina) pada Tikus Putih yang Diinduksi Karagenan
}

\section{Antiinflamation Activity of African Leaf Infusa (Vernonia amygdalina) in Carrageenan Induced White Rats}

\author{
Lusi Agus Setiani, Moerfiah Moerfiah, dan Yulianita Yulianita \\ Program Studi Farmasi, FMIPA, Universitas Pakuan, Bogor, Indonesia \\ Email: lusi.setiani@unpak.ac.id
}

Received: 20 November 2019; Accepted: 12 Juni 2020; Published: 30 Juni 2020

\begin{abstract}
Abstrak
Inflamasi merupakan satu dari respon utama sistem kekebalan terhadap infeksi dan iritasi. Salah satu tanaman obat yang dapat dimanfaatkan sebagai antiinflamasi adalah daun afrika karena mengandung flavonoid. Senyawa flavonoid memiliki efek antiinflamasi yang dapat mengatur metabolisme asam arakhidonat dengan menghambat aktivitas siklooksigenase (COX) dan lipooksigenase. Penelitian ini bertujuan untuk menentukan efektivitas dan menetapkan dosis efektif infusa daun afrika sebagai antiinflamasi pada tikus putih jantan yang diinduksi karagenan. Metode yang digunakan adalah pengukuran udema dengan induksi karagenan $1 \%$ secara subplantar. Hewan uji yang digunakan sejumlah 20 ekor tikus jantan galur sparague dawley yang dibagi dalam 5 kelompok. Setiap kelompok terdiri dari 4 ekor tikus. Kelompok I sebagai kontrol negatif diberikan larutan CMC-Na, kelompok kedua sebagai kontrol positif diberikan Natrium diklofenak dosis $1,26 \mathrm{mg} / 200 \mathrm{~g}$ BB, kelompok III, IV dan V diberikan infusa daun afrika dengan tiga peringkat dosis yakni 100, 150, $200 \mathrm{mg} / \mathrm{kgBB}$. Hasil penelitian menunjukkan bahwa pemberian infusa daun afrika memiliki daya antiinflamasi dan dosis $200 \mathrm{mg} / 200 \mathrm{gBB}$ merupakan dosis paling efektif terhadap penghambatan inflamasi.

Kata kunci : daun afrika (Vernonia amygdalina), antiinflamasi, karagenan
\end{abstract}

\section{Abstract}

Inflammation is one of the immune system's main responses to infection and irritation. One of the medicinal plants that can be used as anti-inflammatory is African leaves because there have flavonoid compounds. Flavonoid compounds have anti-inflammatory effects that can regulate arachidonic acid metabolism by inhibiting cyclooxygenase (COX) and lipooxygenase activity.This study aims to determine the effectiveness and determine the effective dose of African leaf infusion as anti-inflammatory in sparague dawley strain induced carrageenan male white rats. The method used is measurement of udema with subplantar 1\% carrageenan induction.Test animals used were 20 male rats divided into 5 groups. Each group consisted of 4 rats. Group I as a negative control was given CMC-Na solution, the second group as a positive control was given diclofenac sodium with $1.26 \mathrm{mg} / 200 \mathrm{gBB}$ body weight, group III, IV and V were given African leaf infusion with three dose ratings namely $100,150,200 \mathrm{mg} / \mathrm{kgBB}$ bodyweight. The results showed that the infusion of African leaves had Antiinflammatory Activity with dose $200 \mathrm{mg} / \mathrm{kg}$ body weight as the most effective dose against inhibition of inflammation.

Keywords: African leaves (Vernonia amygdalina), anti-inflammatory, carrageenan

\section{PENDAHULUAN}

Masalah kesehatan yang sering timbul di masyarakat adalah radang atau inflamasi. Inflamasi merupakan bagian dari mekanisme pertahanan tubuh, suatu proses dimana sistem kekebalan mengenali dan menghilangkan senyawa asing yang berbahaya seperti patogen, sel yang rusak, senyawa beracun atau iradiasi dan memulai proses penyembuhan (Da Silva et al., 2019). Inflamasi dapat dikategorikan diantaranya yang bersifat akut dan kronis (Zhang et al., 2019), ditandai dengan timbulnya kemerahan, panas, pembengkakan, rasa nyeri yang mengganggu dan hilangnya fungsi dari jaringan (Medzhitov, 2010), bekerja dengan 
menghapus rangsangan berbahaya dan memulai proses penyembuhan (FerreroMiliani et al, 2007). Karena itu, peradangan adalah mekanisme pertahanan vital bagi kesehatan (Nathan dan Ding, 2010).

Saat ini minat masyarakat terhadap pengobatan dengan obat alam semakin meningkat. Pemanfaatan tanaman baik sebagai obat maupun tujuan lain merupakan salah satu fenomena yang terjadi saat ini. Tanaman obat mengandung banyak komponen senyawa aktif dan memiliki berbagai efek farmakologis yang perlu dibuktikan kebenarannya secara ilmiah. Salah satu tanaman obat yang dapat dimanfaatkan sebagai antiinflamasi adalah daun afrika. Menurut penelitian (Nuryanto, dkk, 2017) ektrak etanol daun afrika memperlihatkan aktivitas antiinflamasi melalui mekanisme stabilitas membran. Nilai EC50 aktivitas stabilitas membran ektrak etanol Vernonia amygdalina pada konsentrasi $1 \%$ sebesar $131,81 \pm 2,95 \mathrm{ug} / \mathrm{mL}$ dan pada konsentrasi $10 \%$ adalah sebesar $62,54 \pm 2,5 \mathrm{ug} / \mathrm{mL}$. Semakin kecil konsentrasi EC50 maka semakin efektif aktivitas antiinflamasi sebagai stabilitas membran. Senyawa flavonoid memiliki efek antiinflamasi yang dapat mengatur metabolisme asam arakhidonat dengan menghambat aktivitas siklooksigenase (COX) dan lipooksigenase (Tapas et. al., 2008).

Karagenan merupakan polisakarida yang diekstraksi dari rumput laut famili Euchema, Chondrus, dan Gigartina (Necas \& Bartosikova, 2013). Karagenan sebagai senyawa iritan menginduksi terjadinya cidera sel melalui pelepasan mediator yang mengawali proses inflamasi. Pada saat terjadi pelepasan mediator inflamasi terjadi udem maksimal dan bertahan beberapa jam. Mediator tersebut antara lain histamin, serotonin dan bradikinin (Necas and Bartosikova, 2013). Gejala utama inflamasi langsung terlihat seketika saat penyuntikan karagenan dilakukan. Gejala tersebut antara lain edema, hyperalgesia dan erytema. Edema yang disebabkan karagenan bertahan selama lima jam setelah penyuntikan karagenan dan berangsur-angsur berkurang dalam waktu 24 jam (Fehrenbacher et al., 2012).

Berdasarkan uraian di atas, maka penelitian ini dilakukan untuk mengetahui aktivitas Antiinflamasi dari ekstrak daun afrika yang diperoleh dengan cara infundasi menggunakan dosis efektif sebagai analgesik (Adedapo dan Aremu, 2014) dan antikolesterol (Ardiani, 2017) yaitu 100 $\mathrm{mg} / \mathrm{kg}$ dan $200 \mathrm{mg} / \mathrm{kg}$ dan juga penelitian ini dilakukan untuk mengetahui persen penghambatan Inflamasi serta dosis efektif dari infusa daun afrika sebagai Antiinflamasi yang ditinjau melalui penurunan udem pada telapak kaki tikus putih yang diinduksi karagenan.

Dalam penelitian ini metode yang digunakan adalah pembentukan udem buatan pada telapak kaki tikus dengan menggunakan karagenan sebagai penginduksi udem. Metode ini dipilih karena merupakan salah satu metode pangujian aktivitas antiinflamasi yang sederhana, mudah dilakukan dan sering dipakai. Pengunaan karagenan sebagai penginduksi udem memiliki beberapa keuntungan antara lain tidak meninggalkan bekas, tidak menimbulkan kerusakan jaringan dan memberikan respon yang lebih baik terhadap obat antiinflamasi (Fehrenbacher et al., 2012).

\section{METODE PENELITIAN}

Penelitian telah dilakukan pada bulan Juli di Laboratorium Farmasi Fakultas Matematika dan Ilmu Pengetahuan Alam Universitas Pakuan Bogor.

\section{Alat dan Bahan}

Alat yang digunakan pada penelitian ini antara lain Neraca analitik, blender, cawan uap, oven $\left(\right.$ Memmert $\left.^{\circledR}\right)$, krus, timbangan, tanur $\left(\mathrm{Ney}{ }^{\circledR}\right)$, blender, kandang hewan coba, tempat makan tikus, botol minum tikus, thermometer, stopwatch, spuit injeksi, spuit oral, penangas air, panci infusa, jangka sorong, dan peralatan gelas laboratorium 
lainnya seperti labu ukur, erlenmeyer, corong, cawan petri, pipet tetes, batang pengaduk.

Bahan-bahan yang digunakan yaitu daun afrika (Vernonia amygdalina), Tikus putih jantan galur sparague dawley umur 2-3 bulan dengan berat 200-250mg, aquadest, karagenan, CMC, tablet natrium diklofenak, asam klorida $2 \mathrm{~N}$, larutan amonia $1 \% \mathrm{FeCl}_{3}$, kloroform 1\%, $\mathrm{HCl} 2 \mathrm{~N}$, pereaksi Mayer, pereaksi Dragendrof, pereaksi Bouchardart, $\mathrm{NaCl} 10 \%$, serbuk Mg dan serbuk Zn.

\section{Pembuatan Infusa Daun Afrika}

Daun Afrika (Vernonia amygdalina) diperoleh dari Balai Penelitian Tanaman Obat dan Aromatika (Balitro), Bogor. Dibuat infusa daun afrika dengan konsentrasi $10 \%$ dengan cara ditimbang sebuk simplisia daun afrika sebanyak 10 gram dan ditambahkan $100 \mathrm{~mL}$ aquadest di dalam panci infusa. Setelah itu di tambahkan aquadest dua kali bobot simplisia, dipanaskan diatas penangas air selama 15 menit terhitung mulai suhu mencapai $90^{\circ} \mathrm{C}$ sambil sesekali diaduk. Infusa diserkai selagi panas menggunakan kertas penyaring, ditambahkan air panas melalui ampas hingga volume $100 \mathrm{~mL}$ (Na'imah, 2017).

\section{Rancangan Penelitian}

Pada penelitian ini digunakan Rancangan Acak Lengkap (RAL) dengan 5 kelompok perlakuan. Hewan dipilih sebanyak 20 ekor tikus putih jantan secara acak untuk dibagi menjadi masing - masing terdiri dari 4 ekor. Penentuan jumlah tikus tiap kelompok, dihitung berdasarkan rumus Federer : $\mathrm{t}(\mathrm{r}-1)$ $\geq 15$, dimana $\mathrm{t}$ menunjukkan jumlah perlakuan dan $\mathrm{n}$ menunjukkan ulangan minimal tiap perlakuan.

Masing-masing kelompok perlakuan diinduksi karagenan 1\% sebanyak 0,2 mL. Kelompok perlakuan pada penelitian ini diantaranya :

Kontrol Negatif: Diberikan CMC-Na $0,5 \%$

Kontrol Positif: Diberikan Natrium dikofenak 1,26 mg/200g BB

Dosis 1: Diberikan 100mg/kg BB infusa daun afrika
Dosis 2: Diberikan 150mg/kg BB infusa daun afrika

Dosis 3: Diberikan 200mg/kg BB infusa daun afrika

\section{Persiapan Hewan Uji}

Sebelum dilakukan pengujian tikus ditimbang dan ditentukan homogenitasnya dengan menghitung Coeficient Varian (CV) hewan percobaan dinyatakan homogen bila CV berkisar $10-15 \%$. Tikus diaklimatisasi selama 1 minggu di dalam kandang Laboratorium Farmasi Fakultas Matematika dan Ilmu Pengetahuan Alam Universitas Pakuan Bogor agar menyesuaikan diri dengan lingkungan. Selama masa aklimatisasi tikus diberi makanan dan minum yang seragam dan dilakukan pengamatan yang rutin terhadap keadaan umum hewan uji, seperti berat badan.

\section{Pembuatan Larutan Uji}

Pembuatan Larutan CMC-Na 0.5\%

Sejumlah 0,25 g CMC ditimbang lalu dikembangkan dalam $5 \mathrm{~mL}$ air hangat $\left(60^{\circ} \mathrm{C}\right)$ selama 30 menit. Setelah mengembang, CMC digerus sampai homogen, setelah itu ditambahkan aquadest sampai $50 \mathrm{~mL}$.

\section{Pembuatan Suspensi Natrium Diklofenak}

Satu tablet natrium diklofenak $50 \mathrm{mg}$ digerus dan diambil serbuk sebanyak 45,410 mg. Serbuk dimasukkan kedalam lumpang, kemudian ditambahkan suspensi CMC 0,5\% sampai homogen dan dicukupkan volumenya hingga $10 \mathrm{~mL}$.

\section{Pembuatan Suspensi Karagenan 1\%}

Sebanyak 0,1g karagenan ditimbang lalu dilarutkan dalam natrium klorida $0,9 \%$ dalam labu ukur $10 \mathrm{~mL}$.

\section{Pengujian Antiinflamasi}

Tikus dipuasakan \pm 18 jam sebelum pengujian, air minum tetap diberikan. Pada hari pengujian tikus ditimbang bobotnya dan dikelompokkan secara acak menjadi 5 kelompok perlakuan, masing-masing kelompok terdiri dari 4 ekor tikus. Kelompok I sebagai kontrol negatif diberikan larutan CMC-Na, kelompok kedua sebagai kontrol positif diberikan Natrium diklofenak, kelompok III, IV dan V diberikan infusa daun afrika dengan tiga peringkat dosis yakni 100, 
150, $200 \mathrm{mg} / \mathrm{kgBB}$ secara per oral. Tahap selanjutnya yakni semua kaki kiri hewan yang sudah diberi tanda diinjeksikan dengan larutan karagenan $1 \%$ sebanyak $0,2 \mathrm{~mL}$ secara subplantar (Zahara dan Saputri, 2013). Digunakan selang waktu antara pemberian senyawa uji dengan karagenan adalah 15 menit.

Selanjutnya pengukuran aktivitas antiinflamasi dilakukan dengan mengukur udema kaki tikus dengan menggunakan jangka sorong selama enam jam dimulai dari menit ke-0, 30, 60, 120, 180, 240, 300, 360 setelah diinduksi karagenan 1\% (Aprilianto, 2017). Nilai selisih udema dihitung menggunakan luas AUC dari ketebalan udema kaki tikus terinduksi karagenin pada masing-masing perlakuan di setiap rentang waktu pengukuran dengan metode trapezoid. Rumus perhitungan sebagai berikut :

$$
\begin{aligned}
& \mathrm{AUC}_{t n-1}^{t n}=\frac{T \mathrm{tn}-1+T \mathrm{tn}}{2}\left(t \mathrm{tn}-t_{\mathrm{n}-1}\right) \\
& \text { Keterangan : } \\
& \mathrm{T}_{\mathrm{tn}-1}=\text { Tebal udema kaki Tikus pada tn-1 } \\
& \mathrm{T}_{\mathrm{n}}=\text { Tebal udem kaki Tikus pada } \mathrm{t}_{\mathrm{n}}
\end{aligned}
$$

Aktivitas antiinflamasi dapat di ukur dari persen penghambatan inflamasi dan dihitung dengan rumus berikut :

Penghambatan inflamasi (\%)

$$
=\frac{(A U C 0-\propto) 0-(A U C O-\propto) n}{(A U C 0-\propto) 0} \times 100 \%
$$

Keterangan :

$\left(\mathrm{AUC}_{0-\mathrm{X}}\right)=\mathrm{AUC}_{0-\mathrm{X}}$ Rata-rata dari $\mathrm{AUC}$ ketebalan udema kaki tikus pada kontrol negatif $\left(\mathrm{AUC}_{0-\mathrm{x}}\right) \mathrm{n}=\mathrm{AUC}_{0-\mathrm{x}}$ Rata-rata dari $\mathrm{AUC}$ ketebalan udema telapak kaki tikus yang diberi senyawa uji dengan dosis sebesar $\mathrm{n}$ (mm.menit) (Tjandrawinata et al, 2015., Aprilianto, 2017)

Persen potensi relatif daya antiinflamasi (PRDA) dapat diketahui dengan membandingkan terhadap kelompok kontrol positif, dengan rumus

\section{PRDA =}

$\frac{\text { \%penghambatan inflamasi kel.perlakuan }}{\% \text { penghambatan inflamasi Na diklofenak }}$ x 100\%

(Wicaksana, 2016., Aprilianto, 2017).

\section{Analisis Data}

Analisis data dilakukan untuk mengetahui pengaruh pemberian infusa daun afrika terhadap ketebalan udema telapak kaki tikus yang diinduksi karagenan. Data hasil pengamatan diolah secara statistik menggunakan sidik ragam untuk Rancangan Acak Lengkap dengan metode uji ANOVA yang dilanjutkan dengan uji Duncan. Pengolahan data penelitian dilakukan menggunakan program SPSS 18.0 for windows.

Setelah didapatkan kesimpulan dari analisis sidik ragam selanjutnya data dianalisis kembali dengan menggunakan Uji Lanjut Duncan. Uji Lanjut Duncan ini dilakukan untuk mengetahui perbedaan antar perlakuan. Uji lanjut Duncan dengan taraf kepercayaan $95 \%$ dilakukan jika terdapat perbedaan pada setiap perlakuan, dimana uji lanjut duncan didasarkan pada sekumpulan nilai beda nyata yang ukurannya semakin besar tergantung pada jarak diantara pangkatpangkat dari dua nilai yang dibandingkan. Uji Duncan dapat digunakan untuk menguji perbedaan diantara semua pasangan perlakuan yang mungkin tanpa memperhatikan jumlah perlakuan yang ada dari percobaan tersebut serta masih dapat mempertahankan tingkat nyata yang ditetapkan (Calfee \& Piontkowski, 2016).

\section{HASIL DAN PEMBAHASAN}

Pembuatan serbuk simplisia daun afrika dibuat dengan cara memanen daun afrika segar. Jumlah daun afrika segar yang digunakan yaitu sebanyak $5,5 \mathrm{~kg}$. Hasil serbuk simplisia daun afrika yang didapat setelah melewati beberapa tahap pembuatan simplisia yaitu sebesar $1,2 \mathrm{~kg}$, sehingga diperoleh rendemen sebesar $21,82 \%$.

Serbuk simplisia diekstraksi mengunakan metode infusa. Dibuat infusa daun afrika dengan konsentrasi $10 \%$. Pengujian parameter ekstrak yang dilakukan pada penelitian ini meliputi skrining fitokimia dan uji organoleptik. Dari hasil uji organoleptik infusa daun afrika memiliki warna coklat, bau khas dan rasa pahit.

Hasil skrining fitokimia menunjukkan bahwa infusa daun afrika memiliki 


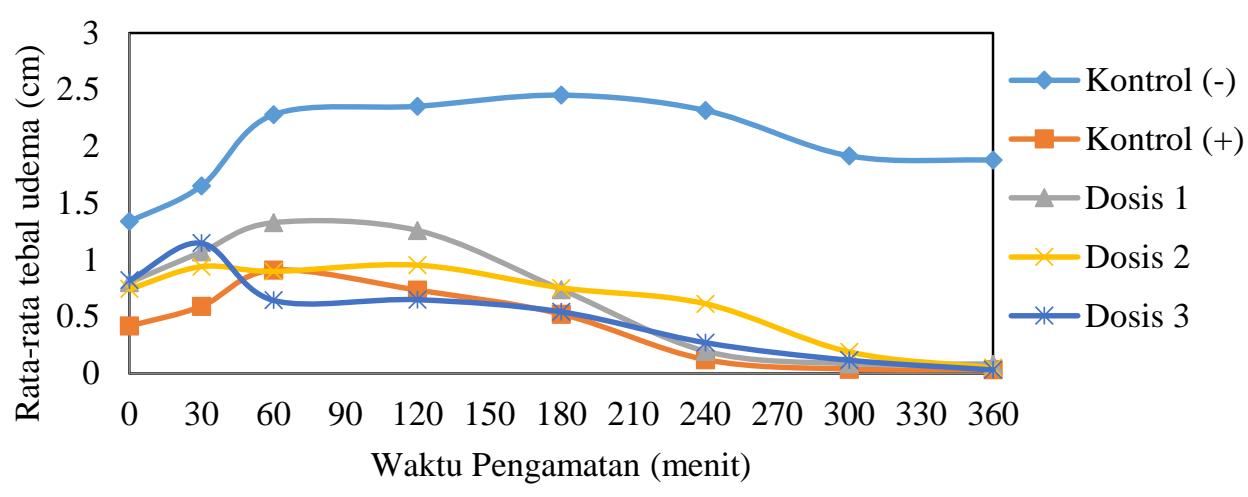

\section{Gambar 1. Grafik Hubungan Rata-Rata Tebal Udem Terhadap Waktu Setelah Pemberian Infusa Daun Afrika}

kandungan alkaloid, flavonoid, saponin dan tanin. Menurut (Ijeh dan Ejike, 2010) daun afrika mengandung saponin, flavonoid, alkaloid, tanin, koumarin, asam fenolat, lignin, xanton dan terpen. Berdasarkan hasil penelitian infusa daun afrika mengandung flavonoid, tanin dan glikosida jantung (Na'imah, 2017).

Hewan percobaan tikus dalam penelitian ini sebelum dilakukan pengujian diaklimatisasi terlebih dahulu selama 7 hari, agar hewan coba terbiasa dengan lingkungan barunya. Berat badan tikus ditimbang dan dihitung nilai $\mathrm{CV}$ setiap harinya selama masa aklimatisasi, dengan parameter apabila $\mathrm{CV}$ mencapai 10-15\% maka berat badan hewan coba bisa dipastikan relatif homogen. Berdasarkan perhitungan sebelum hewan coba diberi perlakuan diperoleh rata-rata bobot hewan coba sebesar 222,25 g dan nilai SD sebesar 32,49 sehingga diperoleh nilai CV sebesar $14,61 \%$ yang berarti bahwa berat badan hewan coba homogen relatif.
Hewan coba diberikan larutan uji secara oral 15 menit sebelum penyuntikan karagenan. Parameter yang diamati adalah tebal udema yang terbentuk akibat induksi karagenan yang diukur menggunakan jangka sorong. Data rata-rata hasil pengamatan tebal udema dapat dilihat pada Gambar 1 .

Dari data rata-rata tebal udema dihitung nilai AUC total (mm.menit). Semakin kecil nilai rata-rata AUC maka semakin tinggi aktivitas anti inflamasinya. Dosis 3 memiliki nilai rata-rata AUC paling kecil dan lebih mendekati kontrol positif dibandingkan dosis 2 dan dosis 1 , hasil ini menunjukan bahwa dosis 3 memiliki aktivitas antiinflamasi yang paling baik. Hasil perhitungan rata-rata AUC total dapat dilihat pada Tabel 1.

Berdasarkan hasil Uji ANOVA menunjukan adanya pengaruh nyata antara pemberian infusa daun afrika terhadap aktivitas antiinflamasi pada hewan coba $(\mathrm{P}<$ 0.05). Untuk melihat perbedaan antar perlakuan, dilakukan uji lanjut Duncan.

Tabel 1. Rata-Rata AUC total (mm.menit)

\begin{tabular}{cc}
\hline Kelompok & $\begin{array}{c}\text { Rerata AUC total } \\
(\mathbf{m m} . \mathbf{m e n i t})(\mathbf{x} \pm \mathbf{S D})\end{array}$ \\
\hline Kontrol Negatif & $109,74 \pm 17,77^{\mathrm{c}}$ \\
Kontrol Positif & $22,68 \pm 3,18^{\mathrm{a}}$ \\
Dosis 1 & $40,94 \pm 4,97^{\mathrm{b}}$ \\
Dosis 2 & $36,06 \pm 18,87^{\mathrm{ab}}$ \\
Dosis 3 & $25,86 \pm 12,88^{\mathrm{ab}}$ \\
\hline
\end{tabular}


Tabel 2. Hasil persen rata-rata penghambatan inflamasi dari setiap kelompok percobaan

\begin{tabular}{cc}
\hline Kelompok & Rata-rata penghambatan inflamasi (\%) \\
\hline Kontrol Negatif & $0 \%$ \\
Kontrol Positif & $79,33 \%$ \\
Dosis 1 & $62,69 \%$ \\
Dosis 2 & $67,14 \%$ \\
Dosis 3 & $76,44 \%$ \\
\hline
\end{tabular}

Tabel 3. Persen potensi relatif daya antiinflamasi (PRDA)

\begin{tabular}{cc}
\hline Kelompok Perlakuan & $\begin{array}{c}\text { Persen Potensi Relatif Daya } \\
\text { Antiinflamasi }\end{array}$ \\
\hline Kelompok negatif & $0 \%$ \\
Kelompok positif & $100 \%$ \\
Dosis 1 & $79,02 \%$ \\
Dosis 2 & $84,63 \%$ \\
Dosis 3 & $96,36 \%$ \\
\hline
\end{tabular}

Berdasarkan hasil uji lanjut Duncan dari perlakuan dosis, dapat dinyatakan bahwa dosis 3 dan dosis 2 memiliki pengaruh yang relatif sama dengan kontrol positif dan pengaruhnya sangat berbeda nyata dengan kontrol negatif.

Hasil perhitungan AUC dari masingmasing kelompok kemudian digunakan untuk menentukan persen penghambatan inflamasi untuk masing-masing kelompok. Persen penghambatan inflamasi dihitung dengan membandingkan selisih rata-rata AUC total kelompok perlakuan dan kontrol positif dengan kontrol negatif. Data perhitungan persen penghambatan inflamasi dapat dilihat pada Tabel 2. Persen penghambatan inflamasi digunakan untuk mengetahui besar kemampuan senyawa uji dalam menurunkan udema kaki hewan uji akibat injeksi karagenan $1 \%$ dengan membandingkan dengan kelompok kontrol negatif.

Berdasarkan data pada Tabel 2, dapat dilihat bahwa dosis 3 memiliki persentase penghambatan inflamasi yang paling tinggi yaitu sebesar 76,44\% dan hampir setara dengan kontrol positif yaitu 79,33\%. Untuk dosis 1 dan dosis 2 memiliki persentase penghambatan inflamasi yang tidak berbeda jauh yaitu masing-masing $62,69 \%$ dan $67,14 \%$. Dari hasil yang diperoleh diduga bahwa semakin besar dosis yang diberikan aktivitas antiinflamasinya semakin tinggi.

Dari hasil persen penghambatan inflamasi yang telah diperoleh kemudian dihitung nilai potensi relatif daya antiinflamasi (PRDA). Tujuannya adalah membandingkan kemampuan bahan uji dalam menghambat inflamasi terhadap kontrol positif. Persen PRDA didapatkan dari hasil perbandingan antara penghambatan inflamasi kelompok perlakuan uji antiinflamasi dengan kelompok kontrol positif.

Berdasarkan data pada Tabel 3, terlihat persen potensi relatif antiinflamasi dari dosis 3 mencapai $96.36 \%$ dan hampir mendekati PRDA kelompok kontrol positif, dari data ini dan ditunjang oleh hasil analisis program statistik SPSS menunjukan bahwa dosis 3 merupakan dosis yang paling efektif untuk menghambat inflamasi.

Karagenan sebagai senyawa iritan menginduksi terjadinya cedera sel melalui pelepasan mediator yang mengawali proses inflamasi. Pada saat terjadi pelepasan mediator inflamasi terjadi udema maksimal dan bertahan beberapa jam. Mediator tersebut antara lain histamin, serotonin dan bradikinin (Necas dan Bartosikova, 2013). Gejala utama inflamasi langsung terlihat seketika saat penyuntikan karagenan dilakukan. Gejala tersebut antara lain udema dan erythema 
(Fehrenbacher et al., 2012). Udema yang disebabkan induksi karagenan bertahan selama 5 jam setelah penyuntikkan karagenan dan berangsur-angsur berkurang dalam waktu 24 jam, dari hasil penelitian terlihat kelompok kontrol negatif terus mengalami peningkatan udema mulai dari menit ke 0 sampai menit ke 180 dan mulai mengalami penurunan pada menit 240 Penurunan udema yang lebih cepat dari teori tersebut dapat disebabkan karena beberapa faktor, hasil penelitian dipengaruhi oleh cara penyuntikan yang merupakan trauma sehingga menyebabkan respon inflamasi, cara pengukuran udema yang kurang tepat serta kemungkinan adanya stress yang terjadi pada tikus dimana yang diketahui saat keadaan stress maka hormone kortisol mengalami peningkatan. Menurut Wolkow et al, terdapat hubungan antara gangguan IL-6 dan pengeluaran kortisol dengan proses terjadinya penghambatan inflamasi, dimana kemungkinan dapat menyebabkan ketidak seimbangan antara system ini. Dari hasil penelitian lain, terdapat korelsi positif antara peningkatan serum kortisol dan sitokin pada beberapa pasien yang mengalami peradangan dengan kondisi depresi yang diukur dengan skala Hamilton Depression ( Jia et al, 2019).

Suatu bahan dinyatakan memiliki efek antiinflamasi jika pada hewan uji yang diinduksi karagenan $1 \%$ mengalami pengurangan pembengkakan hingga 50\% atau lebih (Utami et al, 2011). Pada penelitian ini tiga peringkat dosis perlakuan memiliki potensi yang besar dalam menghambat inflamasi yang ditunjukkan dengan persen penghambatan inflamasi lebih dari $50 \%$.

Kemampuan infusa daun afrika dalam meningkatkan efek antiinflamasi pada tikus putih yang terinduksi karagenan dapat dikaitkan dengan kandungan senyawa yang terdapat didalamnya. Menurut (Astuti, 2016) dan (Tapas et al, 2008) senyawa flavonoid memiliki efek antiinflamasi dengan mekanisme pengaturan metabolisme asam arakhidonat dengan menghambat aktivitas siklooksigenase (COX) dan lipooksigenase.

Pada penelitian ini Natrium diklofenak digunakan sebagai kontrol positif. Natrium diklofenak merupakan antiinflamasi nonsteroid dari derivate fenil asetat yang mempunyai efek farmakologi menghambat sintesis prostalglandin. Natrium diklofenak dipilih karena natrium diklofenak dan metabolitnya dapat mencapai konsentrasi yang cukup tinggi pada telapak kaki yang mengalami peradangan (Schweitzer et al, 2009, Zahara dan Saputri 2013).

\section{KESIMPULAN}

Semua dosis infusa daun afrika memiliki aktivitas sebagai antiinflamasi. Dosis efektif infusa daun afrika sebagai antiinflamasi pada tikus putih yakni dosis $200 \mathrm{mg} / 200 \mathrm{gBB}$ dengan persen potensi relatif daya antiinflamasi sebesar $96,36 \%$.

\section{Daftar Pustaka}

Adedapo A.A. and Aremu O.J. 2014. Anti-Inflammatory, Analgesic and Antioxidant Activities OF Aqueous Leaf Extract Vernonia Amygdalina In some Laboratory Animals, Academic Journal of sciens, 3 (3), 253-256.

Aprilianto, E. 2017. Uji Efek Antiinflamasi Infusa Kulit Alpukat (Persea Americana Mill.) Pada Mencit Jantan Galur Swiss Terinduksi Karagenin. Skripsi. Yogyakarta. Program Study Farmasi Universitas Sanata Dharma.

Ardiani, R.. 2017. Efek Antikolesterol Ekstrak Etanol Daun Afrika (Vernonia amygdalina DEL.) pada tikus. Journal penelitian pendidikan mipa. Universitas Muslim Nusantara AlWashliyah

Astuti, P. (2016). The Ability of Anti-Inflammatory Jatropha curcas Leaf Extract at COX-2 
Expression on Monocytes were Exposed LPS. Proceeding ICMHS, 154-157.

Calfee, R., \& Piontkowski, D. (2016). Design and analysis of experiments. Handbook of Reading Research, 63-90. https://doi.org/10.2307/2983009

Da Silva, D. M., Langer, H., \& Graf, T. (2019). Inflammatory and molecular pathways in heart failure-ischemia, HFpEF and transthyretin cardiac amyloidosis. International Journal of Molecular Sciences, 20(9). https://doi.org/10.3390/ijms20092322

Fehrenbacher, J. C., Vasko, M. R., \& Duarte, D. B. (2012). Models of inflammation: Carrageenan- or unit 5.4 complete freund's adjuvant (CFA)-induced edema and hypersensitivity in the rat. Current Protocols in Pharmacology, SUPPL.56, 1-7. https://doi.org/10.1002/0471141755.ph0504s56

Ferrero-Miliani L, Nielsen OH, Andersen PS, Girardin SE. Chronic inflammation: importance of NOD2 and NALP3 in interleukin-1beta generation. Clin Exp Immunol. 2007;147(2):227-235. doi:10.1111/j.1365-2249.2006.03261.x

Ijeh, I.L., dan Ejike, C.E.C.C. 2010. Current Prespective on The medical Potential of Vernonia amygdalina Del. Pharmacol Res. 51(2):177-123.

Fehrenbacher, J. C., Vasko, M. R., \& Duarte, D. B. (2012). Models of inflammation: Carrageenan- or unit 5.4 complete freund's adjuvant (CFA)-induced edema and hypersensitivity in the rat. Current Protocols in Pharmacology, SUPPL.56, 1-7. https://doi.org/10.1002/0471141755.ph0504s56

Medzhitov R. Inflammation 2010: new adventures of an old flame. Cell. 2010; 140(6):771776. doi:10.1016/j.cell.2010.03.006

Nathan C, Ding A. Nonresolving inflammation. Cell. 2010; 140(6): 871-882. doi:10.1016/j.cell.2010.02.029

Na'imah, M. 2017. Efek Analgesik Infusa Daun Afrika (Vernonia amygdalina L.) Pada Mencit Yang Diinduksi Asam Asetat. Skripsi. Surakarta. Universitas Muhamadiyah Surakarta

Necas, J., \& Bartosikova, L. (2013). Carrageenan: A review. Veterinarni Medicina, 58(4), 187205. https://doi.org/10.17221/6758-VETMED

Nuryanto, M.K., Paramita, S., Iskandar, A., Ismail, S., Ruslim, A.K. 2017. Aktivitas Antiinflamasi In Vitro Ekstrak Etanol Daun Vernonia amydalina Delile Dengan Pengujian Stabilitas Membran. Jurnal Sains dan Kesehatan. Vol, 1. No. 8.

Schweitzer, A., Hasler-Nguyen, N., Zijlstra, J. 2009. Prefential uptake of the non steroid antiinflammatory drug diclofenak into inflamed tissues after a single oral dose in rats. BMC Pharmacology, 9:5

Tapas, R, Sakarkar, M., \& Kakde, B. 2008. Flavonoid as Nutraceutical: A Review. Tropical Journal of Pharmaceutical Research.

Tjandrawinata. R.R., Djunarko, I., Fenty, dan Hendra, P., 2015. Antiinflamation Effect of Bioactive Fraction DLBS0553 Containing Phaleria Macrocarpa an Nigella Sativa on Animal Model. International Journal of Pharmacy and Pharmaceutical Sciences.,7(1), 14.

Utami, E.T., Kuncoro, R.A., Hutani, I.R., Sari, F.T., Handajani, J. 2011. Efek Antiinflamasi Ekstrak Daun Sembukan (Paederia scandes) Pada Tikus Wistar. Majalah Obat Tradisional, 
$16(2), 95-100$

Wolkow, A., Aisbett, B., Reynolds, J., Ferguson, S. A., \& Main, L. C. (2015). Relationships between inflammatory cytokine and cortisol responses in firefighters exposed to simulated wildfire suppression work and sleep restriction. Physiological Reports, 3(11). https://doi.org/10.14814/phy2.12604

Wicaksana, L. D. 2016. Uji Efek Antiinflamasi Dekokta Herba Baru Cina (Artemesia vulgaris L.) Pada Mencit Betina Galur Swis Terinduk Karegenin Menggunakan Plethysmometer. Skripsi. Universitas Sanata Dharma. Yogyakarta.

Zahara, R., Saputri, F.C. 2013. Uji Aktivitas Antiinflamasi Minyak Atsiri Daun Kemangi (Ocium americanum L.) Pada Tikus Jantan Yang Dinduksi Kragenan. Skripsi. Universitas Indonesia.

Zhang, X., Wu, X., Hu, Q., Wu, J., Wang, G., Hong, Z., \& Ren, J. (2019). Mitochondrial DNA in liver inflammation and oxidative stress. Life Sciences, 236(April). https://doi.org/10.1016/j.lfs.2019.05.020 